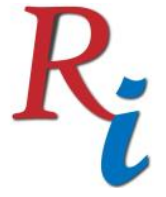

Asia Proceedings of Social Sciences

(APSS)

www.readersinsight.net/APSS

\title{
PERCEIVED EFFECTIVE SANCTIONS AND ITS EFFECT ON CUSTOMER INITIAL TRUST IN AN ONLINE VENDOR: A \\ CONCEPTUAL PAPER
}

\section{Wong Chiet Bing*}

Azman Hashim International Business School

Universiti Teknologi Malaysia

Malaysia

\section{Khalil Md Nor}

Azman Hashim International Business School

Universiti Teknologi Malaysia

Malaysia

*Corrosponding author's Email: wongchietbing@ gmail.com

Peer-review under responsibility of $3^{\text {rd }}$ Asia International Multidisciplanry Conference 2019 editorial board

(http://www.utm.my/asia/our-team/)

(C) 2019 Published by Readers Insight Publisher, lat 306 Savoy Residencia, Block 3 F11/1,44000 Islamabad. Pakistan,

info@ readersinsight.net

This is an open access article under the CC BY-NC-ND license (http://creativecommons.org/licenses/by-nc-nd/4.0/). 


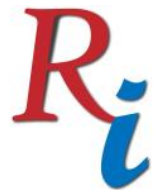

\section{Asia Proceedings of Social Sciences \\ (APSS) \\ www.readersinsight.net/APSS}

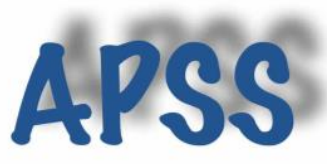

\section{Rese a r ch H i g h I g h t s}

Perceived effective sanction, in this study, refer to perception that the customers have the ability to impose punishment on the vendor if the vendor does not fulfill his or her promises. This paper is aimed to examine the effect of perceived effective sanctions on trusting beliefs and trusting intention on an unfamiliar online vendor. This study proposes that a strong perception of effective of imposing sanctions on an unfamiliar online vendor may lead to customers' trustworthiness perception of the vendor and subsequently, their tendency to rely on the vendor. This paper also proposes the methodology to validate the research model.

\section{Graphical A bstract}

The following figure shows the proposed research model in this study.

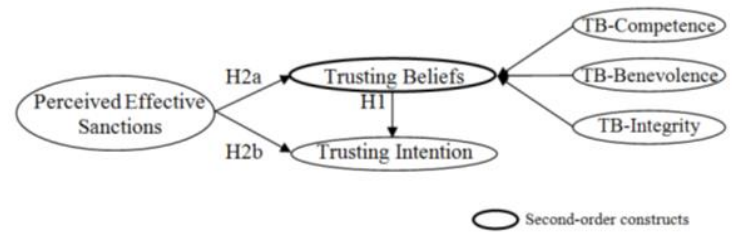

\section{Research Objectives}

In the literature, McKnight's trust studies (i.e. McKnight, Choudhury, and Kacmar (2002a), (2002b)) have conceptualized trust by specifically dividing it into two separate yet interrelated components (i.e. trusting beliefs which refers to one's beliefs that the other person is competent, benevolence, and has integrity where trusting beliefs is an important antecedent to another trust component, that is, trusting intention which refers to one's willingness to depend on the other person). They have studied trust specifically on an unfamiliar online vendor, one with whom the customer has no past experience or interaction, also called initial trust in this study. Perceived effective sanctions has been suggested by Bock, Lee, Kuan, \& Kim (2012) as antecedent to initial trust, however, trust that they conceptualized, in fact, referred to trusting beliefs as termed by McKnight's trust studies. They have examined the effect of perceived effective sanctions on trusting beliefs only but not on trusting intention. It is essential to examine the effect of perceived effective sanctions on trusting intention as according to McKnight's trust studies, compared to trusting beliefs, trusting intention indicates a firmer commitment to trust, has better predicting power on specific behavioral intention that will lead one to indulge in certain behaviors (i.e. purchase) and one who has trusting intention is not solely due to one's trusting beliefs but also due to other factors in which one's perceived effective sanctions could be one of them. Examining its direct effect on trusting intention should enhance the predicting power on trusting intention. Based on the researchers' knowledge, McKnight's conceptualization is best describing trust and thus it is worthwhile to incorporate perceived effective sanction in McKnight's trust model to develop a greater understanding on how it affects customers' initial trust on an unfamiliar online vendor. At the same time, improve the Bock, Lee, Kuan, \& Kim's (2012) work through a proposed direct relationship between the constructs. In particular, this study aims to examine the effect of perceived effective sanctions on trusting beliefs and trusting intention on an unfamiliar online vendor. 


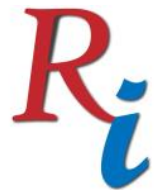

\section{Asia Proceedings of Social Sciences \\ (APSS) \\ www.readersinsight.net/APSS}

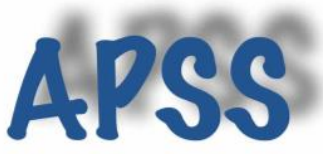

\section{Methodology}

This study suggests quantitative method to validate the conceptual model. Due to university students are the most connected, experienced and frequent users of the Internet Drennan, Mort, \& Previte (2006) and based on Hair, Hult, Ringle, \& Sarstedt's (2017) 10 times rules and equation of determining sample size, a total of 120 local university students are proposed to participate in the study. The study involves two phases. In a computer laboratory, the respondents will asked to visit an unfamiliar or non-reputable website. This is to ensure the respondents visit a website for the first time so that initial trust as what we aim to study can be investigated. After the website browsing, the respondents are given a questionnaire which will solicit their perception on sanctions, trusting beliefs, and trusting intention. The collected data will be analyzed statistically using smartPLS.

\section{Conclusion}

According to the proposed research model and based on the literature, logic, theoretical, and empirical support, this study proposes that trusting beliefs positively affect trusting intention where in the context of online transaction, if customers strongly sense that an unknown online vendor is kind hearted, capable, and honest, these will increase their tendency to rely on the vendor. Futhermore, this study suggests that perceived effective sanctions positively affects trusting beliefs and trusting intention on an unfamiliar online vendor. We propose that customers with a strong perception on effective of imposing sanctions on an unfamiliar online vendor will have higher beliefs that the vendor will behave trustworthily and consequently have higher tendency to rely on the vendor. In particular, this study contributed academically by proposing a relationship between perceived effective sanctions and trusting intention; which it has not yet been explored in the literature.

\section{Acknowledgement}

The authors would like to thank the Zamalah Universiti Teknologi Malaysia for their financial assistance.

\section{References}

Bock, G. W., Lee, J., Kuan, H. H., \& Kim, J. H. (2012). The progression of online trust in the multi-channel retailer context and the role of product uncertainty. Decision Support Systems, 53, 97-107.

Drennan, J., Mort, G. S., \& Previte, J. (2006). Privacy, Risk Perception, and Expert Online Behavior: An Exploratory Study of Household End Users. Journal of Organizational and End User Computing, 18, $1-22$.

Hair, J. F., Hult, G. T. M., Ringle, C. M., \& Sarstedt, M. (2017). A primer on partial least squares structural equation modeling (PLS-SEM).

McKnight, D. H., Choudhury, V., \& Kacmar, C. (2002a). Developing and Validating Trust Measures for eCommerce:An Intergrative Typology. Information Systems Departments, 3, 334-359.

McKnight, D. H., Choudhury, V., \& Kacmar, C. (2002b). The impact of initial consumer trust on intentions to transact with a web site: A trust building model. Journal of Strategic Information Systems, 11, 297323. 